\title{
Transactiekostentheorie en de nieuwe zorgmarkt
}

\section{John Groenewegen}

SAMENVATTING Het organisatieprincipe van de Nederlandse gezondheidsmarkt is in de loop der jaren verschoven van een publieke naar een private zaak. De wijzigingen, die per 1 januari 2006 in werking zijn getreden, impliceren duidelijk de introductie van meer marktwerking en een stap in de richting van volksverzekering naar meer schadeverzekering. Zorgverzekeraars kiezen het ziekenhuis, waarmee zij een contract afsluiten, consumenten kiezen hun verzekeraar en de marktwerking wordt op allerlei manieren gefaciliteerd. In dit artikel wordt de gezondheidszorg belicht vanuit het perspectief van de transactiekostentheorie. Welke transacties zijn in de gezondheidszorg te identificeren en hoe zouden die op de meest efficiënte wijze gecoördineerd kunnen worden? Is vanuit het ziekenhuis verticale integratie gewenst, of dienen juist behandelingen te worden afgestoten?

\section{Inleiding}

Het economisch denken heeft ook in de gezondheidszorg zijn intrede gedaan: de consumenten worden gestimuleerd bewust te kiezen tussen zorgverzekeraars, de zorgverzekeraars onderhandelen met zorgaanbieders over de meest gunstige contractuele voorwaarden, zorgaanbieders fuseren en integreren,

Prof. dr. J.P.M. Groenewegen is hoogleraar Economie van Infrastucturen aan de TU Delft en als bijzonder hoogleraar Institutionele Economie verbonden aan de Erasmus Universiteit Rotterdam en als bijzonder hoogleraar Comparatieve Economie aan de Universiteit van Utrecht. Hij is General Secretary van EAEPE (European Association for Evolutionary and Political Economy) en voorzitter van VIPE (Vereniging van Politieke en Institutionele Economie). ziekenhuizen dreigen failliet te gaan en staan te koop en als klap op de vuurpeil blijkt een berekening in omloop van wat een extra levensjaar zou mogen kosten (QALY) ${ }^{1}$. Het doel van het invoeren van meer marktwerking is het bereiken van een grotere doelmatigheid in de gezondheidszorg. Doordat consumenten en zorgverzekeraars kunnen kiezen worden aanbieders gedwongen de meest doelmatige oplossingen te kiezen. De discussie richt zich vooral op het inkaderen van de marktwerking, opdat de doeleinden van Publiek Belang niet (te zeer) in het geding komen.

De liberalisering van de gezondheidsmarkt en de introductie van marktcontracten wordt in belangrijke mate theoretisch onderbouwd door inzichten uit de Nieuwe Institutionele Economie (NIE) en met name vanuit de transactiekostentheorie. Het gaat dan om vraagstukken ten aanzien van de efficiënte coördinatie van transacties tussen consumenten van gezondheidszorg en de verzekeraars, tussen de verzekeraars en de ziekenhuizen en binnen de ziekenhuizen bijvoorbeeld om de relatie met de medisch specialisten. Ook de vraagstukken van verticale integratie van ziekenhuizen, het uitbesteden van bepaalde activiteiten naar zelfstandige behandelcentra (ZBCs), of het diversificeren in de richting van de thuiszorg, zijn onderwerp van de transactiekostentheorie.

In dit artikel wordt de gezondheidszorg belicht vanuit het perspectief van de transactiekostentheorie. Welke transacties zijn in de gezondheidszorg te identificeren en hoe zouden die op de meest efficiënte wijze gecoördineerd kunnen worden? Is vanuit het ziekenhuis verticale integratie gewenst, of dienen juist behandelingen te worden afgestoten?

Dit artikel is als volgt opgebouwd: in paragraaf 2 wordt een aantal ontwikkelingen in de gezondheidszorg geschetst, die voor een analyse vanuit transactiekosten relevant zijn. In paragraaf 3 wordt het model 
van transactiekostentheorie nader uiteengezet, waarna in paragraaf 4 de toepassing volgt. Conclusies sluiten het artikel af.

\section{Bewegingen op de gezondheidsmarkt}

Het organisatieprincipe van de Nederlandse gezondheidsmarkt is in de loop der jaren verschoven van een publieke naar een private zaak. De wijzigingen, die per 1 januari 2006 in werking zijn getreden, impliceren duidelijk de introductie van meer marktwerking en een stap in de richting van volksverzekering naar meer schadeverzekering. Zorgverzekeraars kiezen het ziekenhuis, waarmee zij een contract afsluiten, consumenten kiezen hun verzekeraar en de marktwerking wordt op allerlei manieren gefaciliteerd. Kort gezegd gaat het om (Keuzenkamp 2006):

- Een verlaging van toetredingsdrempels voor zorgaanbieders dankzij de Wet Toelating Zorginstellingen. Dit is belangrijk voor het introduceren van concurrentie tussen aanbieders.

- Geen verplicht contracteren meer tussen zorgaanbieders en verzekeraars. Partijen kunnen naar eigen inzicht contracten afsluiten met wie de voorkeur heeft. Dat impliceert voor de consument dat zorgvuldig moet worden nagegaan of de verzekeraar een contract heeft met het ziekenhuis en zorginstelling in de regio en zo ja, wat de condities van die contracten zijn.

- De bekostiging van de ziekenhuiszorg is voor tien procent vrijgegeven: aanbieder en verzekeraar kunnen onderhandelen over de prijs.

- In de toekomst kunnen zorgaanbieders winst maken. $\mathrm{Nu}$ is bij wet geregeld dat ziekenhuizen stichtingen zijn, maar minister Hoogervorst heeft aangekondigd dat niet later dan 2012 (dus mogelijk eerder) ziekenhuizen vennootschappen met aandeelhouders kunnen zijn.

- Per 1 januari 2006 is een basisverzekering ingevoerd, waardoor het onderscheid ziekenfonds/particulier is vervallen. De verzekeraars hebben een acceptatieplicht en als een verzekeraar onevenredig veel 'risicoverzekerden' in het bestand heeft, dan wordt gecompenseerd via het vereveningsfonds. De acceptatieplicht betekent dat geen selectie op risico mogelijk is en Nederland daardoor een fundamenteel andere markt kent dan bijvoorbeeld Amerika.

Het doel is te komen tot een meer doelmatige inrichting van de gezondheidszorg. De consumenten kiezen de verzekeraar die een gewenst pakket biedt tegen de laagste premie, hetgeen druk zet op verzekeraars zo efficiënt mogelijk te werken en in te kopen bij de aanbieders van gezondheidszorg tegen de laagste prijs. De verzekeraar zet dus de ziekenhuizen en andere zorgaanbieders onder druk.

\section{Van functiegerichte budgettering naar DBC's}

Voor januari 2006 werden de middelen in de gezondheidszorg via het budgetmechanisme verdeeld: de Commissie Tarieven Gezondheidszorg (CTG) stelde de tarieven vast en betaling geschiedde op basis van productieparameters, zoals aantallen opnamen en verpleegdagen in het ziekenhuis. De aanbodsturing kende problemen, die bekend zijn van de centraal geleide economieën: geen invloed van de consument op het aanbod, geen onderscheid tussen efficiënte en inefficiënte aanbieders, hoge bureaucratische kosten van informatievoorziening, controlemechanismen en sancties. Met andere woorden: tussen principaal (ministerie) en agenten (ziekenhuizen) bestonden problemen, die conform de principaal-agent theorie zijn terug te voeren op verschillende doeleinden van de principaal en de agent en het bestaan van informatieasymmetrie tussen de partijen. Kort gezegd: budgetmechanismen zijn aanbodgestuurd, waardoor marktprikkels tot efficiëntie en innovatie ontbreken. Het functiegerichte budgetteringssysteem is opgevolgd door de allocatie van middelen via de 'Diagnose Behandeling Combinaties (DBC's), waardoor meer vraagsturing mogelijk is. Voor alle behandelingen in het ziekenhuis is een nauwkeurige omschrijving gemaakt en is vastgesteld wat de gehele behandeling van diagnose tot ontslag uit het ziekenhuis zou mogen kosten. Een DBC geeft de vraag naar zorg weer en per 1 januari 2005 onderhandelen de vragers (zorgverzekeraars) met de ziekenhuizen over de prijzen van DBC's. Er is voorzichtig met deze marktwerking begonnen: voor 90 procent van de behandelingen worden de tarieven centraal vastgesteld door de Centrale Tarieven Gezondheidszorg (CTG) en slechts 10 procent behoort tot het 'segment B', waarover partijen contracten mogen afsluiten en over de prijzen mogen onderhandelen. Het is de bedoeling dat segment B wordt uitgebreid en dat slechts een beperkt deel (segment A) altijd buiten de marktwerking zal blijven (bijvoorbeeld spoedeisende hulp).

De invoering van DBC's heeft ook tot doel de productieprocessen binnen de ziekenhuizen transparanter te maken: als de kosten van een afdeling afwijken van de norm dan is dat aanleiding tot nader onderzoek.

\section{Concurrentie bewaken}

Partijen voelen zich door de markt alleen gedwongen efficiënt te handelen als er daadwerkelijk sprake is van concurrentiedruk. Zoals op alle markten zullen partijen ook op de gezondheidsmarkt proberen 
concurrentie uit te schakelen; door middel van het opbouwen van machtsposities kunnen in onderhandelingen prijzen en voorwaarden in de contracten aan de ander worden opgelegd. De Nederlandse Mededingingsautoriteit $(\mathrm{NMa})$ is de algemene waakhond voor het behoud van de concurrentie en ziet toe op de concentratie in de markt en eventuele kartelvorming. De nieuwe Zorgautoriteit in oprichting (ZAio) is het orgaan dat specifiek toeziet op de uitvoering van de zorgverzekeringswet: het nakomen van de acceptatieplicht door de verzekeraar wat betreft de basisverzekering, het verbod op premiedifferentiatie en dat de polis biedt wat wettelijk verplicht is.

De marktwerking is zonder meer nog bescheiden, maar de weg naar meer markt is ingeslagen en dat lokt veel anticiperend gedrag van partijen uit. Fusies tussen verzekeraars en fusies tussen ziekenhuizen duiden op schaalvergroting, specialisatie en vooral ook het vormen van machtsblokken. Ziekenhuizen besteden bepaalde activiteiten uit aan particuliere b.v.s, die zij veelal zelf hebben opgezet, waarvan zij vaak enig aandeelhouder zijn en de zorgverzekeraar regelmatig als medefinancier optreedt. De medisch specialisten maken ook bewegingen waarbij zij zich losweken uit de organisatie van het ziekenhuis in de richting van een contract als toeleverancier. Kortom: de invoering van de nieuwe wet en het geboden perspectief op meer veranderingen richting markt in de nabije toekomst, leiden tot acties van alle betrokken partijen (consumenten, zorgaanbieders en verzekeraars), waardoor het proces aanmerkelijk wordt versneld ${ }^{2}$.

\section{Inzichten uit de transactiekostentheorie}

Wat voor gedrag en welke uitkomsten mogen worden verwacht volgens het perspectief van de transactiekostentheorie? Elders zijn de basisprincipes van die theorie uiteengezet (Groenewegen 2004); in deze paragraaf worden enkele voor de gezondheidszorg relevante elementen nader toegelicht.

Uit het basismodel in figuur 1 blijkt dat de actoren (consumenten, verzekeraars en zorgaanbieders) beperkt rationele actoren zijn, die minimalisatie van de transactiekosten nastreven. Vanuit het perspectief van de transactiekostentheorie is de vraag voor hen dus steeds hoe een transactie van gezondheidzorg het meest doelmatig kan worden gecoördineerd. Dat kan bijvoorbeeld tussen de medisch specialist en het ziekenhuis een contract zijn, maar ook een vorm van verticale integratie, of een strategische alliantie. Met andere woorden: partijen hebben verschillende mogelijkheden hun transacties te coördineren en de keuze van de gewenste 'mode of governance' wordt bepaald door de hoogte van de transactiekosten. Die hoogte wordt bepaald door de aard van de investeringen, de frequentie en de mate van onzekerheid (Groenewegen, 2004).

Volgens de transactiekostentheorie hebben de actoren een 'beperkte rationaliteit' en kunnen zich opportunistisch gedragen. Hun rationaliteit kent grenzen, waardoor niet alle onzekerheden kunnen worden overzien, laat staan in contracten kunnen worden gevangen. De gewenste informatie is bijvoorbeeld niet tegen acceptabele kosten verkrijgbaar, of kan door de actoren vanwege de complexiteit niet worden verwerkt tot een optimale beslissing. Het gevolg is dat de contracten tussen partijen incompleet zullen zijn: er zijn open einden waar later de partij met de meeste kennis of macht zijn voordeel mee kan doen. Dat is te meer een probleem als niet bekend is hoe de ander zich in zo'n situatie zal gedragen. Zal zij alleen haar eigen nut maximaliseren, of zal er volgens een bepaalde beroepsethiek worden gehandeld? Sterker: zal de ander in de aanloop naar het contract informatie achterhouden of bewust onjuiste informatie verspreiden, waardoor de inhoud van het contract wordt gemanipuleerd? Als partijen geen langdurige relatie hebben en die ook niet nastreven, dan moeten actoren zich indekken tegen dergelijk opportunistisch gedrag. Dat kan de transactiekosten fors doen stijgen. Neem de situatie tussen de verzekeraar en de consument. Zijn de premies in 2006 en 2007 onverstandig laag en een gevolg van een opportunistische prijzenslag, waardoor in volgende jaren onvermijdelijk een forse stijging plaatsvindt? De consument zal in het contract een (lage) lange termijn prijs willen vasteggen, terwijl de verzekeraar de voorkeur geeft aan het openhouden van opties gelet op de onzekerheid met betrekking tot de technologie, regelgeving, concurrentie, e.d. Neem de situatie tussen een verzekeraar en een ziekenhuis. Door de informatieasymmetrie (het ziekenhuis heeft veel meer en betere informatie over de kwaliteit van haar diensten dan de verzekeraar) moet de verzekeraar rekening houden met informatieverstoring. Door te investeren in marktonderzoek, 'benchmarking' en 'monitoring', kan de verzekeraar de balans in de onderhandeling meer in evenwicht brengen, maar de daaraan verbonden transactiekosten kunnen sterk oplopen.

Figuur 1 toont dat de individuele actoren vanuit de motivatie om kosten te minimaliseren en behept met de eigenschappen van beperkte rationaliteit en opportunistisch gedrag, proberen op niveau 3 van figuur 1 de meest efficiënte institutionele arrangementen 


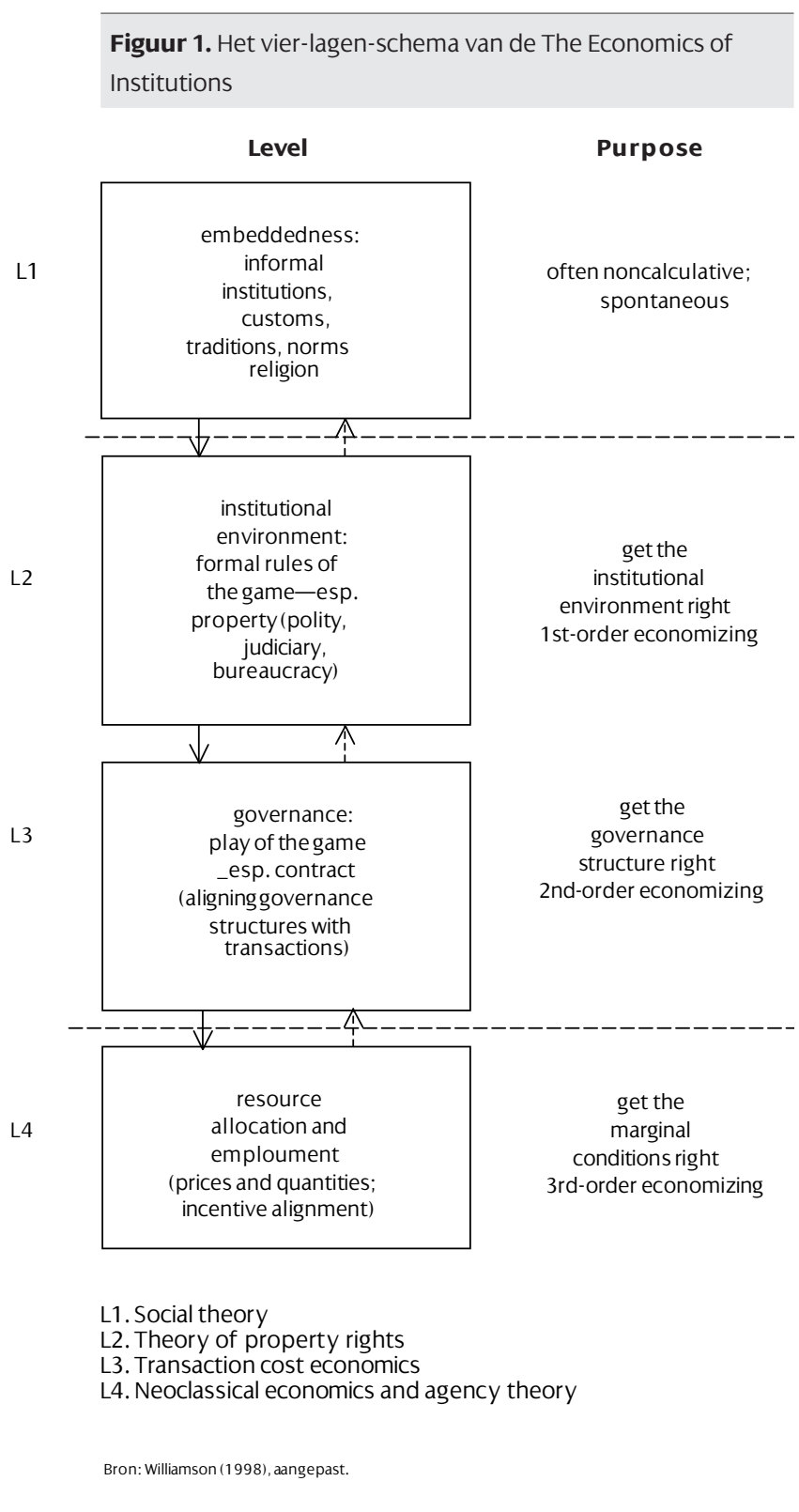

(contracten, organisaties en hybriden) op te zetten. Dat is een proces, waarbij de actoren vooruit kijken en anticiperen op het gedrag van de tegenpartij. Om zich in te dekken worden contracten voorzien van clausules en worden organisaties ter controle en voor conflictoplossing opgezet. Verondersteld wordt dat alle partijen opereren onder een regiem van concurrentie en daarom gedwongen zijn de meest efficiënte oplossingen te bedenken of na te volgen.

Laag 1 en 2 in figuur 1 geven de omgeving aan waarbinnen de actoren handelen en hun transacties coör- dineren. Er is een omgeving van impliciete instituties, van normen en waarden, die voorschrijven wat de gang van zaken behoort te zijn. Het is de laag van de cultuur, die in de gezondheidszorg een belangrijke rol speelt. Neem bijvoorbeeld de beroepsethiek van een arts en verpleegster. Stel dat theoretisch de transactie volop de mogelijkheid biedt tot opportunistisch gedrag en de arts de patiënt behandelingen voorschrijft die onnodig zijn, dan zou dergelijk gedrag uit kunnen blijven op grond van de heersende normen en waarden.

Risicoselectie en afwenteling, zoals de praktijk is bij verzekeraars in de Verenigde Staten, passen (nog) niet in de Nederlandse cultuur. Iedereen moet toegang hebben tot betaalbare en kwalitatief hoge voorzieningen, die tot het basispakket worden gerekend. Illustratief is in dit verband de discussie over de noclaimkorting.

Het is niet alleen zo dat de normen en waarden verschillen tussen landen en regio's (Nederland en Amerika) en tussen sectoren (farmaceutische industrie en de gezondheidszorg), maar de normen en waarden zijn ook aan verandering onderhevig. Er wordt in dat verband gewezen op het bestaan van een relatie tussen enerzijds het invoeren van het marktmechanisme in tal van sectoren van de economie waar voorheen de allocatie verliep via bureaucratische verdelingsmechanismen en anderzijds het aantasten van de normen en waarden in die sectoren. Traditioneel zijn transacties in sectoren als het onderwijs, gezondheidszorg en nutsbedrijven gebaseerd op vertrouwen, betrokkenheid en gemeenschapszin. Daarin passen geen contracten met clausules tegen mogelijk opportunistisch gedrag, want het gaat uiteindelijk bij alle medewerkers om 'de goede zaak': het geven van hoogwaardig onderwijs, het redden van mensenlevens, het gelukkig maken van minder bedeelden. Kort gezegd komt de hypothese erop neer dat contracten, die zijn gebaseerd op het beginsel van wantrouwen (en daardoor 'dichtgetimmerd' moeten worden), de cultuur van betrokkenheid en de beroepsethiek ondergraven. In termen van figuur 1 is sprake van een terugkoppeling van institutionele arrangementen naar de normen en waarden; een relatie die in de transactiekostentheorie wordt genegeerd (Groenewegen, 2004).

De omgeving bestaat niet alleen uit informele instituties, maar ook uit expliciete formele instituties, zoals regels en wetten. De veranderingen in de wet op de gezondheidszorg vinden plaats op niveau twee van formele instituties. Wat is nu de hypothese, die de transactiekostentheorie genereert en die voorspelt 
hoe in de gezondheidszorg in geval van verandering van de formele instituties de arrangementen zich zullen aanpassen? Kort gezegd komt het erop neer dat in de gezondheidszorg verticale integratie zal plaatsvinden als de transacties plaatsvinden in een omgeving, die onzekerder wordt en/of investeringen met zich brengen, die specifiek met de transactie zijn verbonden. Een centraal begrip in de transactiekostentheorie is de zogenaamde 'asset specificity': de mate waarin partijen investeringen doen in 'assets', die niet, of in mindere mate voor andere transacties kunnen worden gebruikt. Dergelijke 'transactiespecifieke investeringen' kunnen fysieke middelen betreffen (specifieke laboratoria, of behandelingsapparatuur), menselijk kapitaal (specialisten) of de capaciteit, die alleen wordt aangehouden om aan de vraag van een specifieke verzekeraar te kunnen voldoen (zogenaamde 'dedicated assets'). Het bestaan van een hoge mate van transactiespecifieke investeringen biedt de mogelijkheid van opportunistisch gedrag, dat de kosten van het afsluiten van contracten sterk kan doen stijgen. Een ziekenhuis zal behandelingen binnen haar eigen organisatie houden en niet uitbesteden als de behandelingen investeringen vergen, die alleen waarde hebben voor de onderhavige specifieke transactie en daarbuiten nauwelijks van waarde zijn. In dat geval worden de onderhandelingen met een toeleverancier zeer gecompliceerd omdat, nadat de toeleverancier de investeringen heeft gedaan, deze met handen en voeten aan het afnemende ziekenhuis is gebonden. De toeleverancier wil dan allerlei clausules in het contract, die mogelijk opportunistisch gedrag van de afnemer uitsluiten. Met andere woorden, de contractkosten lopen zo op dat internalisering in de organisatie efficiënter is.

\section{Toepassing van transactiekostentheorie op de gezondheidsmarkt}

Door de invoering van de wettelijke veranderingen op niveau 2 van figuur 1 is een aantal transacties in de gezondheidszorg fundamenteel veranderd. Tussen de consument en de verzekeraar is nu sprake van een nagenoeg reguliere koper-verkoper relatie, idem tussen de verzekeraar en de zorgaanbieders, zoals ziekenhuizen en de thuiszorg. Ook binnen de instellingen is sprake van uitbesteding, integratie, en dergelijke. Bovendien betekent de invoering van de nieuwe wetgeving dat een belangrijke taak is weggelegd voor toezicht op de concurrentie en het gedrag van de verschillende partijen. Welke inzichten zijn bruikbaar voor het analyseren van die nieuwe situatie vanuit het perspectief van de transactiekostentheorie?

\section{Consumenten}

De relatie tussen de consument en de zorgverzekeraar is sterk veranderd. Het kiezen en veranderen van zorgverzekeraar kan voor de consument met aanzienlijke transactiekosten gepaard gaan. Hoe transparant is de markt? Doordat de contractverplichting voor verzekeraars is vervallen, zullen verzekeraars relatief snel een monopoliepositie in een regio kunnen opbouwen. Het is voor de consument zaak zorgvuldig te onderzoeken wie welke contracten heeft met welke zorginstellingen in de regio. De transactiekosten voor de consument worden aanzienlijk verlaagd door het aanbod van vergelijkende informatie op bijvoorbeeld internet. Gebleken is dat veel consumenten de zoeken onderhandelingskosten uit de weg gaan door zich aan te sluiten bij collectieve contracten. Daar is de eerste slag in 2006 om de gunst van de consument gestreden met Achmea als winnaar en Agis als verliezer. Ook bestaat de indruk dat de consument zich in zijn gedrag van verzekeraar te wisselen, niet zozeer door een ingewikkelde vergelijking van de inhoud van de aangeboden pakketten heeft laten leiden, maar door de prijs. Het is tussen de verzekeraars vooralsnog vooral een prijzenslag geweest vergelijkbaar met de supermarkten. De verwachting is dat bij de volgende ronde de inhoud van de verzekeringen een grotere rol zal spelen en dat collectieve verzekeringen meer gedifferentieerde pakketten zullen aanbieden: voor het gezin met jonge kinderen, voor het oudere echtpaar, voor de bemiddelde tweeverdieners, et cetera. Ook is te verwachten dat in de toekomst de consumenten hun gedrag laten afhangen van de reputatie van de verzekeraar en de relatie die met hem is opgebouwd. Dat geldt nog sterker voor de relatie tussen de consument als patiënt met het ziekenhuis en de arts. Gezondheidszorg wordt beschouwd als een 'ervaringsgoed', waarvan de prijselasticiteit van de vraag beperkt is.

\section{De zorgverzekeraar}

De zorgverzekeraars hebben een voorkeur voor consumenten met een laag risicoprofiel. Bekend is de tegengestelde tendens in verzekeringsmarkten van het probleem van 'adverse selection', waarbij patiënten met een hoog risicoprofiel de premie opjagen en daarmee de patiënten met een laag risicoprofiel uit het bestand van de verzekeraar doen vertrekken. Het fenomeen van 'adverse selection' is gebaseerd op informatieasymmetrie tussen de verzekeraar en de consument (de laatstgenoemde weet meer over zijn gezondheid en gedrag). In het nieuwe systeem is afgesproken dat de verzekeraars voor het basispakket een acceptatieplicht hebben en in geval van een bestand 
met een hoog risicoprofiel een compensatie ontvangen uit het zogenaamde vereveningsfonds.

In de relatie tussen de verzekeraar en de zorgaanbieder, zoals het ziekenhuis, kunnen de onderhandelingen over de contracten tot hoge transactiekosten leiden, omdat de gezondheidsmarkt op een groot aantal punten afwijkt van het theoretische marktmodel. In theorie leiden op de markt onderhandelingen tussen partijen tot evenwicht onder de voorwaarde dat geen sprake is van dominantie en een te grote informatieasymmetrie. Traditioneel wordt de gezondheidsmarkt echter gekenmerkt door een grote onzekerheid (welke zorg is wanneer nodig?), door heterogene diensten (veelal, maar niet altijd, gaat het om complexe, multidisciplinaire op de patiënt toegesneden behandelingen), een beperkt aantal aanbieders leidt tot monopolistische en oligopolistische structuren en tot slot is er de aanbodgeïnduceerde vraag (de arts weet wat goed is voor de patiënt). De invoering van DBC's heeft de markt transparanter gemaakt, maar het aantal en de aard van de af te sluiten contracten kunnen de transactiekosten gemakkelijk uit de pan doen rijzen. Van veel betekenis is in dit verband de macht van de verzekeraars die gaan 'shoppen' bij de aanbieders met het doel de prijs naar beneden te drukken. Met betrekking tot de collectieve contracten was een korting toegestaan van 2,5 tot 10 procent: het 'shopgedrag' leidde tot algemene kortingen van 10 procent.

Verder speelt de horizontale concentratie een rol, die overigens aan beide zijden van de markt plaatsvindt. Fusie tussen verzekeraars, tussen ziekenhuizen en ook in de thuiszorg zijn aan de orde van de dag. Sterk staan in de onderhandelingen door een groot marktaandeel is de filosofie die lijkt te domineren.

\section{Ziekenhuizen}

De ziekenhuizen en daarbinnen de medisch specialisten, beschikken over veel specifieke informatie, hetgeen aanleiding kan zijn tot opportunistisch gedrag. Als de prikkel van het ziekenhuis het vergroten van de omzet wordt (prijs en hoeveelheid), dan mag worden verwacht dat artsen geneigd zijn de patiënt meer en duurdere behandelingen voor te schrijven dan strikt noodzakelijk is. Deze vorm van zogenaamde 'moral hazard' kan er ook toe leiden dat artsen en ziekenhuizen patiënten selecteren en de patiënten die economisch minder interessant zijn, pogen af te wentelen. In welke mate van die mogelijkheden tot opportunistisch gedrag daadwerkelijk gebruik zal worden gemaakt, hangt in belangrijke mate af van de context waarbinnen de actoren opereren (laag 1 en 2 in figuur 1).
"Upcoding" is een ander voorbeeld van mogelijk opportunistisch gedrag. De DBC's zijn te beschouwen als de producten van een ziekenhuis. Het is denkbaar dat voor het behandelen van een kwaal meerdere producten beschikbaar zijn. De idee van 'upcoding' betreft het gedrag van artsen dat zij in geval van alternatieve DBC's het meest lucratieve zullen kiezen.

Een ander probleem is dat van kwaliteitsverlies. DBC's bevatten niet alle elementen die bij een behandeling relevant zijn. De aandacht en betrokkenheid van het personeel voor een patiënt is bijvoorbeeld moeilijk in een code te vatten, maar voor de kwaliteit van de dienst van essentiële betekenis. De verwachting is dat de artsen en instellingen op kwaliteit zullen beknibbelen teneinde de financiële doelstellingen te realiseren.

\section{Specialisatie, integratie en diversificatie}

De transactiekostentheorie biedt niet alleen inzicht in de relaties tussen actoren, maar ook hoe organisaties zoals ziekenhuizen zich zullen opstellen als het gaat om de vraag wat zij 'in-huis' zullen produceren en wat zij zullen afstoten en via contracten zullen laten toeleveren. Voorspeld wordt dat de goed planbare zorg, waarmee weinig specifieke investeringen zijn gemoeid, zullen worden afgestoten naar ZBC's. Die kunnen zich dan specialiseren en schaalvoordelen behalen, waarvan alle partijen de vruchten kunnen plukken. De eerste bevindingen lijken die hypothese te bevestigen ${ }^{3}$.

Acht ziekenhuizen onderzoeken momenteel de mogelijkheden van een alliantie om onder één merknaam te kunnen gaan opereren. ${ }^{4}$ Het ligt in de lijn van de verwachtingen dat daarna fusies volgen. Ook is sprake van vergaande samenwerking tussen 'cure' en 'care', waardoor nieuwe conglomeraten ontstaan met thuiszorg, verpleging en ziekenhuis onder één dak. ${ }^{5}$ Deze ontwikkelingen worden veelal aangekondigd als stappen in de richting van efficiëntere structuren, maar zijn vaak ingegeven door denkbeelden over het vergroten van marktsegmenten en het bedrijven van machtspolitiek. De transactiekostentheorie belicht alleen de efficiëntie en veronderstelt dat onder de voorwaarde van voldoende concurrentie de actoren organisatiestructuren zullen opzetten die de transactiekosten minimaliseren. Vanuit de transactiekostentheorie wordt relatief weinig aandacht besteed aan de inhoud van de mededingingswetgeving en de sectorspecifieke regulering. Het is eigenlijk andersom: organisatievormen zoals verticale integratie, die vanuit de traditionele leer van de Industriële Organisatie worden gezien als pogingen om een machtpositie op 
te bouwen, worden door de transactiekostenbenadering beschouwd als efficiënte manieren om transacties te coördineren. Dit leidt in het algemeen tot het standpunt dat de overheid zich op grote afstand van de markt moet opstellen en een zeer terughoudend mededingingsbeleid moet voeren. Echter, ook wordt onderkend dat sommige markten specifieke overheidsaandacht behoeven, hetzij omdat de karakteristieken sterk afwijken van het theoretische concurrentiemodel (bijvoorbeeld het natuurlijk monopolie, of grote informatieasymmetrie), dan wel omdat het publieke belang erg groot is. De gezondheidszorg is mijns inziens een dergelijke markt. Het specifieke overheidstoezicht richt zich niet alleen op het voorkomen en verwijderen van inefficiënte marktstructuren, maar ook op het beteugelen van het opportunistische gedrag dat kan leiden tot selectie, afwenteling en kwaliteitsverlies.

\section{Marktfacilitering en markttoezicht}

Het nieuwe zorgstelsel heeft geleid tot de introductie van een aantal nieuwe instituties die moeten waken voor opportunistisch gedrag en de marktwerking moeten faciliteren.

In het DBC informatiesysteem (DIS) worden alle gegevens van ziekenhuizen, verzekeraars en ZBC's opgeslagen. Alle behandelingen worden geregistreerd, zodat een goed beeld ontstaat over de gevolgen van de invoering van de nieuwe regels op de inhoud van de behandelingen.

DBC-Onderhoud is de stichting die de DBC's bijstelt en nieuwe DBC's toevoegt. Alle partijen in de zorg zijn in de stichting vertegenwoordigd en momenteel wordt voorgesteld het declaratiesysteem aan te passen. $^{6}$

De rol van de NMa en de ZAio betreft vooral het toezicht op het gedrag van partijen ${ }^{7}$. Dat die rol van belang is, blijkt bijvoorbeeld uit de recente ervaring met de tandartsen 8 .

Het verdient sterk aanbeveling een systeem van kwaliteitscontrole in te voeren, zodat de mogelijkheden om gunstige financiële resultaten te boeken ten koste van de kwaliteit van de dienstverlening worden geminimaliseerd.

Vanuit het perspectief van transactiekosten kan worden geconstateerd dat een vergelijking van de kosten van het nieuwe zorgstelsel met het oude systeem niet alleen oog moet hebben voor de verandering in de transactiekosten voor de individuele partijen (consumenten, zorgverzekeraars en zorgaan- bieders), maar dat ook de kosten verbonden aan het invoegen van allerlei toezichthoudende organen in de berekeningen worden meegenomen.

\section{Conclusies}

Vanuit het perspectief van de transactiekostentheorie is de inefficiëntie van het oude zorgstelsel te wijten aan het ontbreken van marktwerking, die actoren stimuleert tot het opzetten van mechanismen die de transacties in de gezondheidszorg op de meest efficiënte wijze coördineren. Marktprikkels leiden ertoe dat alle actoren zowel hun productiekosten als hun transactiekosten minimaliseren. Echter, het transactiekostenperspectief toont ook hoe contracten tussen consumenten en verzekeraars en tussen verzekeraars en zorgaanbieders gelegenheid kunnen bieden tot opportunistisch gedrag. Dat gedrag wordt door de marktpartijen in het contract afgedekt (private ordening) of door toezichthoudende instanties bewaakt (publieke ordening). In beide gevallen is sprake van het oplopen van de transactiekosten. Ook wijst de transactiekostentheorie op het belang van de institutionele context: welke prikkels gaan uit van de (in)formele instituties op het gedrag van de actoren? Het is goed mogelijk dat opportunistisch gedrag in principe tot de mogelijkheden behoort, maar dat de waarden en normen in de sector het onmogelijk maken. Ook biedt het transactiekostenperspectief aanknopingspunten om de ontwikkeling van de relatie tussen de actoren te analyseren: wat is de rol van reputatie, welke rol speelt vertrouwen?

De transactiekostentheorie is minder geschikt voor het analyseren van machtspolitiek; de horizontale, verticale en conglomerate fusies en overnamen zullen voor een belangrijk deel niet voortkomen uit het streven naar efficiëntere structuren, maar voortkomen uit het bedrijven van machtspolitiek. De transactiekostentheorie biedt slechts één perspectief, terwijl de weerbarstige werkelijkheid uit meerdere perspectieven bestaat. Het is voor de politiek dan ook zaak een geïntegreerd beeld te ontwikkelen, waarin gezondheidszorg meer is dan economie alleen.

\section{Literatuur}

Keuzenkamp, H. (2006), Zorg te koop, Economenblad, jaargang 29, april/ mei, pp. 16-17.

Groenewegen, J. (2004), Inzichten uit de institutionele economie; over vraagstukken van organisatie, Maandblad voor Accountancy en Bedrijfseconomie, jg. 78, no. 11, november, pp. 515-523.

Williamson, O.E. (1998), Transaction Cost Economics: How it work; Where it is Headed, De Economist, vol. 146, no. 1, pp. 23-58. 


\section{Noten}

1 Gezondheidskosten kunnen worden uitgedrukt in de kosten per kwaliteitsjaar. Een 'Quality Adjusted Life Year' (QALY). Een jaar met 100 procent kwaliteit telt voor 1. De World Health Organization stelde in 2002 voor een limiet te stellen aan interventies in de gezondheid van drie maal het bruto nationaal product (BNP) per hoofd van de bevolking. Voor Nederland komt dat neer op $€ 90.000$,-. De Raad voor de Gezondheidszorg heeft voorgesteld dat een QALY niet meer dan $€ 80.000$ mag kosten. Deze normen bestaan nog niet, maar geven een indicatie van de soort van discussie die ons te wachten staat.

2 Een soortgelijke ontwikkeling trad op bij de invoering van het bachelor-master systeem aan de Nederlandse universiteiten. Toen na de Bologna verklaring duidelijk werd dat ook in Nederland de nieuwe tweedeling een feit zou worden anticipeerden de universiteiten op die toekomst door snel uit eigen beweging stappen in die richting te nemen. De idee was dat snelle invoering een wapen in de concurrentiestrijd om de gunst van de student zou zijn. In de zorgmarkt zijn soortgelijke argumenten hoorbaar.

3 De NRC van 23 april 2006 bericht over de heup- en kniestraat in het zelfstandig Orthopedisch Centrum Maxima te Eindhoven.

4 NRC 7 juni 2006

5 De tweestrijd tussen ondernemerschap en dienstbaarheid, tussen winst en ethiek, is duidelijk zichtbaar in de thuiszorg. In een sector waar het beroep veelal als een roeping werd ervaren is traditioneel sprake van een grote betrokkenheid, die zich moeilijk laat rijmen met de recente ontwikkelingen van fusies, dreigende faillissementen en directeuren met topsalarissen. Een actueel voorbeeld dat veel discussie heeft losgemaakt, is het faillissement van het Slotervaart ziekenhuis. Woningbouwcorporatie De Key koopt het noodlijdende Slotervaart ziekenhuis dat zich door middel van een advertentie in het Financieel Dagblad te koop aanbood in juni 2006. De Key werkt samen met stichting Cordaan, De Stichting van het Slotervaart ziekenhuis fuseert met de stichting Cordaan, waarbij overigens geen eurocent over de toonbank gaat. Het is de wereld van typisch Nederlandse instellingen: particuliere stichtingen, corporaties en verenigingen, die met publiek geld diensten verzorgen waar de politiek in principe een grote zeggenschap over wil hebben. Fusies in die wereld vinden plaats met gesloten beurzen. Het gaat om het realiseren van maatschappelijke doelen door op zakelijke leest geschoeide stichtingen, corporaties of verenigingen, maar de vraag dringt zich op of in geval van meer marktwerking ook niet de spelregels van 'goed bestuur' op die instellingen van toepassing zouden moeten zijn.

6 In de NRC van 3 oktober 2006 wordt geconstateerd dat het huidige systeem te veel onduidelijkheden bevat en niet eenduidig aangeeft welke DBC's mogen /moeten worden gedeclareerd. Dat heeft ertoe geleid dat specialisten in 2006 voor 600 miljoen euro teveel declareerden bij de verzekeraars. De kern van het aangepaste systeem is dat de artsen niet meer zelf de DBC's invoeren, maar dat met het registeren van de diagnose en de behandeling de computer daar automatisch een DBC aan koppelt.

7 Voorbeeld van fusies in de thuiszorg betreft de (aangekondigde) fusie tussen Evean (Purmerend, Alkmaar, Meppel) en Meander (Veendam) met GGZ Drenthe (Assen), die fuseren met een instelling voor geeste- lijke gezondheidszorg tot de op een na grootste Zorgonderneming in Nederland (700 miljoen omzet). Erasmus Medisch Centrum in Rotterdam is met 792 miljoen inkomsten in 2005 de grootste. De traditionele scheiding tussen thuiszorg, verpleeghuizen, geestelijke gezondheidszorg en ziekenhuizen wordt doorbroken.

8 Het voorbeeld van de fraude in de kronen bij de tandartsen is illustratief. Markten vereisen toezicht en daar is in 1995, toen de tandheelkundige zorg voor volwassenen uit het ziekenfondspakket verdween, veel verandering in gekomen. Zo verdween de 'adviserende tandarts' en de Commissie Tandheelkundige Statistiek, waardoor landelijke informatie over de behandelingen door tandartsen niet meer beschikbaar is. Vergelijking met andere Europese landen is niet goed meer mogelijk. In de Inspectie gezondheidszorg is het toezicht op de tandartsen een ondergeschoven kindje. De klachtenprocedure voor patiënten is moeilijker geworden: de klachtencommissie geeft nu alleen nog een advies waarmee een tijdrovende juridische procedure kan worden begonnen. Standaarden voor tariefopbouw zijn ondoorzichtig, waardoor bij complexe behandelingen de tarieven onderling sterk kunnen verschillen. De praktijk is ondoorzichtig, waardoor kwaadwillende tandartsen goedkope kronen uit lagelonenlanden kunnen declareren tegen kosten van kronen uit eigen land. 